\title{
RESEARCH OF USAGE LEVEL OF SIMULATION METHODS IN PRODUCTION AND LOGISTICS IN THE CZECH REPUBLIC
}

\author{
[Průzkum úrovně využití simulačních metod ve výrobě a logistice v ČR]
}

\author{
Pavel Šenkýŕr \\ ${ }^{1}$ W2W s.r.o., Rybkova 23, 60200 Brno \\ Email:polo@calypsa.cz
}

\begin{abstract}
This article describes the ressearch of the business process mapping, modelling and process simulation (BPM) support tools usage and rate in Czech companies in years 2009 and 2010. The article is also aimed on some choosen attributes influencing the measure of BPM usage, on managerial willingness to improve their decision and planning processes and on the outsourcing possibilities. Eight hypothesis was solved on the representative sample of the Czech small, middle and big sized companies with activities in main twelve fields of activities. The very importent part of the article/reserch is the part aimed on the usage of the BPM superstructure - optimalisation module.
\end{abstract}

Keywords: model, optimalization, process mapping, simulation.

JEL classification: D21, O22

Doručeno redakci: 28.6.2011; Recenzováno: 27.5.2013; 6.2.2013; 26.6.2013; Schváleno k publikování: 23.9.2014

\section{Úvod}

Cílem průzkumu, který proběhl formou elektronického i osobního dotazníkového šetření v období březen 2009 - červen 2010, bylo zjistit postoje manažerů, kteří se s mapováním, modelováním a simulací podnikových procesů - jakožto s novým nástrojem manažerské podpory - již střetli, získat odpovědi na relevantní zásadní otázky a provést vyhodnocení výsledků (včetně ověření platnosti přijatých pracovních hypotéz). Protože předpokládaná hloubka znalostí o simulaci se zásadně liší podle funkčního postavení respondenta v podniku, byl průzkum rozdělen na dva dílčí výzkumy podle cílové skupiny. U první skupiny, kterou tvořili manažeři a techničtí pracovníci, bylo předmětem zájmu např. zjistit jejich názory na problémy, které lze řešit simulací a zjistit metody a nástroje, které se používají v podniku k optimalizaci procesů. Druhá skupina, tvořená přímo lidmi, kteří se simulací v podniku již zabývají a řeší simulační projekty, byla dotazovaná na to, jaké projekty se nejčastěji řeší simulací, zda je běžně využíván optimalizační modul nebo jaké jsou hlavní bariéry širšího použití simulačních nástrojů.

\section{Subjekt průzkumu}

Subjektem průzkumu byly, s ohledem na princip vhodného úsudku (Punch 2008), firmy působící v České republice po dobu delší pěti roků, s počtem zaměstnanců vyšším než deset. Velikost firem byla posuzována dle počtu zaměstnanců a výše tržeb. U vzorku bylo předpokládáno a potvrzeno normální rozdělení. Rozsah vzorku byl stanoven kombinací výše uvedeného úsudku se statistickou metodou. Nákladové kriterium použito nebylo - vzhledem ke skutečnosti, že dotazník byl šířen elektronicky. V rámci statistického přístupu byl pro daný typ výzkumu použit vztah dle Kozla (2006) pro výpočet minimálního rozsahu vzorku - n, který vychází z normálního rozdělení.

$$
n \geq \frac{\left(t^{2} \cdot p \cdot q\right)}{\Delta^{2}}
$$


kde:

$\mathbf{t}^{2}$ představuje požadovaný koeficient spolehlivosti (při hodnotě 1 je zaručena minimální pravděpodobnost výsledku tvrzení $68,3 \%$, při hodnotě 2 pak 95,4 \% a při hodnotě $3-99,7 \%$ ),

p [\%] představuje předpokládanou relativní četnost respondentů, $\mathrm{z}$ dotazovaného vzorku, znalých zkoumané problematiky - resp. přiklánějících se $\mathrm{k}$ jedné variantě ( $\mathrm{v}$ tomto př́padě využívajících metody MMS),

q [\%] přestavuje relativní četnost respondentů, v dotazovaném vzorku, neznalých problematiky - resp. přiklánějících se $\mathrm{k}$ druhé variantě, $\mathrm{v}$ príípadě, že poměr $\mathrm{p}$ a $\mathrm{q}$ není znám a nemůže být odhadnut, použije se, pro p i pro q, hodnota 0,5

a $\Delta[\%]$ je maximální př́ípustná chyba.

Při dosazení hodnot $\mathrm{t}=2, \mathrm{p}=0,5, \mathrm{q}=0,5$ a požadované maximální chybě $\Delta=5 \%$, získáme údaj o minimálním rozsahu zkoumaného vzorku $\mathrm{n}=400$ respondentů se spolehlivostí $95 \%$.

Při použití koeficientu spolehlivosti 3, pak získáme údaj o minimálním rozsahu vzorku $\mathrm{n}=900$.

Pilotní studie a předvýzkum byly provedeny iterační metodou. Pilotní studie byla provedena formou nestandardizovaných rozhovorů na náhodně zvoleném vzorku patnácti zástupců působících na manažerských pozicích ve zkoumaných firmách. Cílem těchto nestandardizovaných rozhovorů bylo předběžně ověřit zvolené výzkumné předpoklady, upřesnit výzkumné otázky a získat podněty pro sestavení dotazníku. Před samotným šetřením byl proveden předvýzkum na vzorku dalších třiceti firem, kdy následně došlo k reformulaci otázek a byly upřesněny ty otázky, jež nebyly vybraným respondentům zcela jasné. Dále bylo na základě předvýzkumu rozhodnuto, že podmínkou pro odpovědi v oblastech používané metodiky řízení procesů nebude vlastnictví tzv. certifikátů jednotlivých složek integrovaného managementu (kvalita, bezpečnost práce, ochrana životního prostředí). Rovněž byly provedeny finální úpravy dotazníkového elektronického rozhraní a byly doplněny některé varianty odpovědí. Výsledná forma dotazníku byla použita pro vlastní šetření.

Veškerá data nezbytná pro naplnění cílů práce byla tedy získána technikou písemného on-line dotazníkového šetření. Data získaná dotazníkovým šetřením byla následně anonymizována. Výhodou techniky on-line dotazníkového šetření bylo následné relativně snadné zpracování získaných dat a dále např́klad i redukce zkreslení. Nevýhodou pak, v některých případech, omezenost možností motivace respondentů k vyplnění dotazníku a dále pak nutnost udržet respondentovu pozornost po celou dobu vyplňování dotazníku. Dotazník byl rozčleněn na úvodní část, která obsahovala seznámení s účelem šetření, žádost o spolupráci, motivační část a hypertextový odkaz na vlastní dotazník. Zjišt'ovací část dotazníků byla zaměřena na hlavní problematiku, byla využita baterie otázek, kdy respondenti volili jednu z několika možných opovědí. V př́ípadě, že respondent nechtěl, nemohl odpovědět nebo nevěděl odpověd' na nějakou otázku, mohla být daná otázka vynechána a nebo mohl odpovědět zcela volně do prostoru pro poznámku.

Při on-line šetření bylo elektronickou poštou (e-mailem) osloveno 1188 firem - respondentů. Tento počet vyhovoval dle kriteria (1). Dotazník byl formou zdvořilé e-mailové zprávy, obsahující příslušný odkaz, směrován na zástupce firem, u kterých byl předpoklad, že budou ochotni ke spolupráci a budou disponovat informacemi potřebnými k zodpovězení dotazníku. Jednalo se zejména o manažery, vlastníky, společníky apod. Tito byli před vlastním zasláním dotazníku osloveni zdvořilou žádostí o spolupráci na výzkumu. S vybranými - zejména vlastníky většího počtu společností - byl proveden př́ležitostný briefing za účelem vydání pokynu podřízeným ke spolupráci. Z oslovených respondentů daný dotazník vyplnilo 635 respondentů - firem, což představuje úspěšnost oslovení 53,45 \%. Z uvedeného počtu odeslaných dotazníků bylo vyčleněno celkem 21 dotazníků pro zásadní neúplnost nebo pro nemožnost doplnit údaje o zveřejněné výsledky hospodaření. Následně byly provedeny testy 
normality rozdělení a bylo vyřazeno dalších 30 „extrémních“ dotazníků, které by svým zařazením do zpracování znehodnocovaly věrohodnost vypočtených statistických charakteristik. Do výzkumu nakonec bylo zařazeno $\mathbf{5 8 4}$ zodpovězených dotazníků z obou skupin dotazovaných, což představuje $49,15 \%$ z dotázaného počtu respodentů. Strukturu respondentů - firem, dle oboru činnosti, obratu a počtu zaměstnanců, znázorňují grafy na obr. 1. - obr. 3

Obrázek 1: Graf relativních četností oborů činnosti ve zkoumaném vzorku

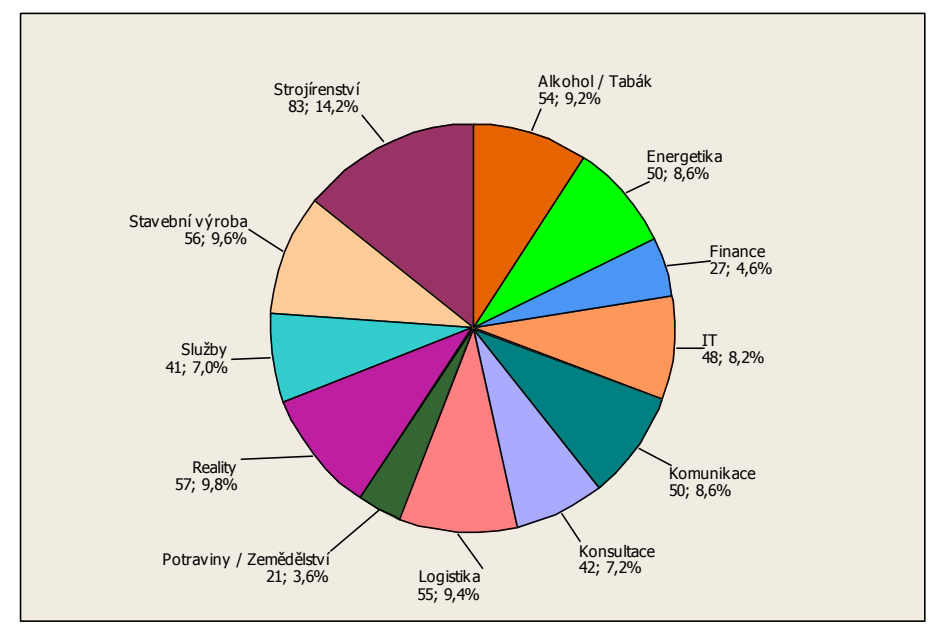

Zdroj: autor

Obrázek 2: Graf rozdělení respondentů - firem, dle tržeb [mil. Kč]

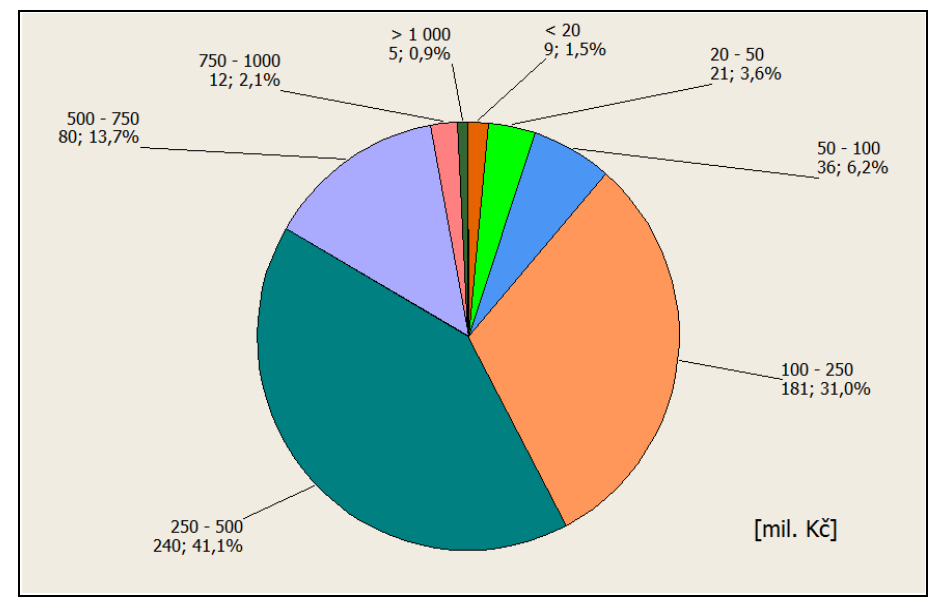

Zdroj: autor 
Obrázek 3: Graf rozdělení respondentů - firem, dle počtu zaměstnanců

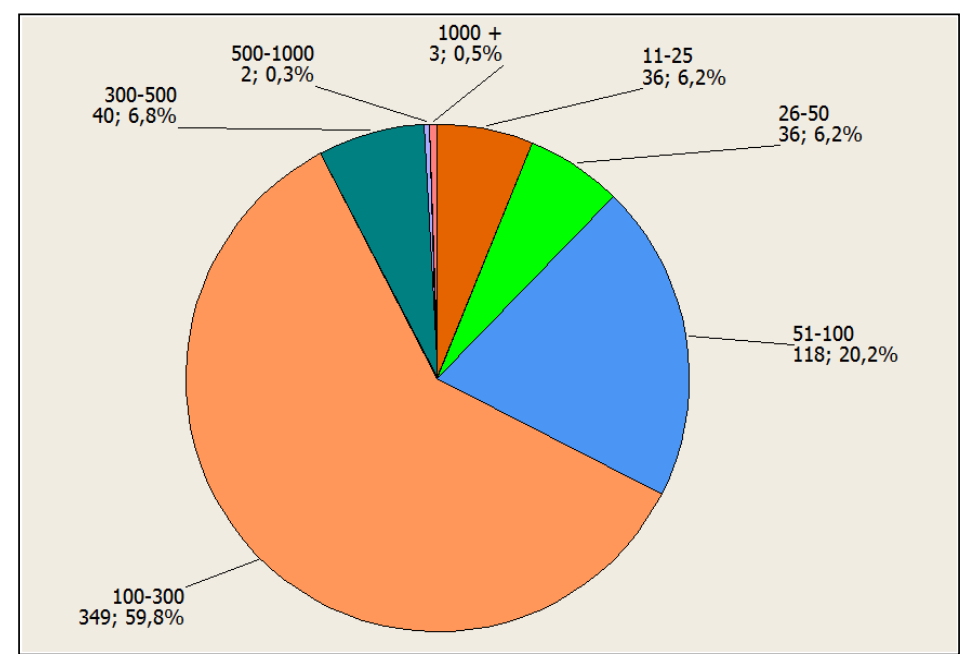

Zdroj: autor

U zkoumaného vzorku dat byly dále provedeny Kolmogorov - Smirnofův a Anderson Darlingův testy normálního rozdělení dle tržeb a dle počtu zaměstnanců - viz obr. 4 až 7 . Oba testy, v obou prrípadech, normální rozdělení potvrdily.

Obrázek 4: Graf - Kolmogorov - Smirnofưv test normality dle tržeb v mil. Kč

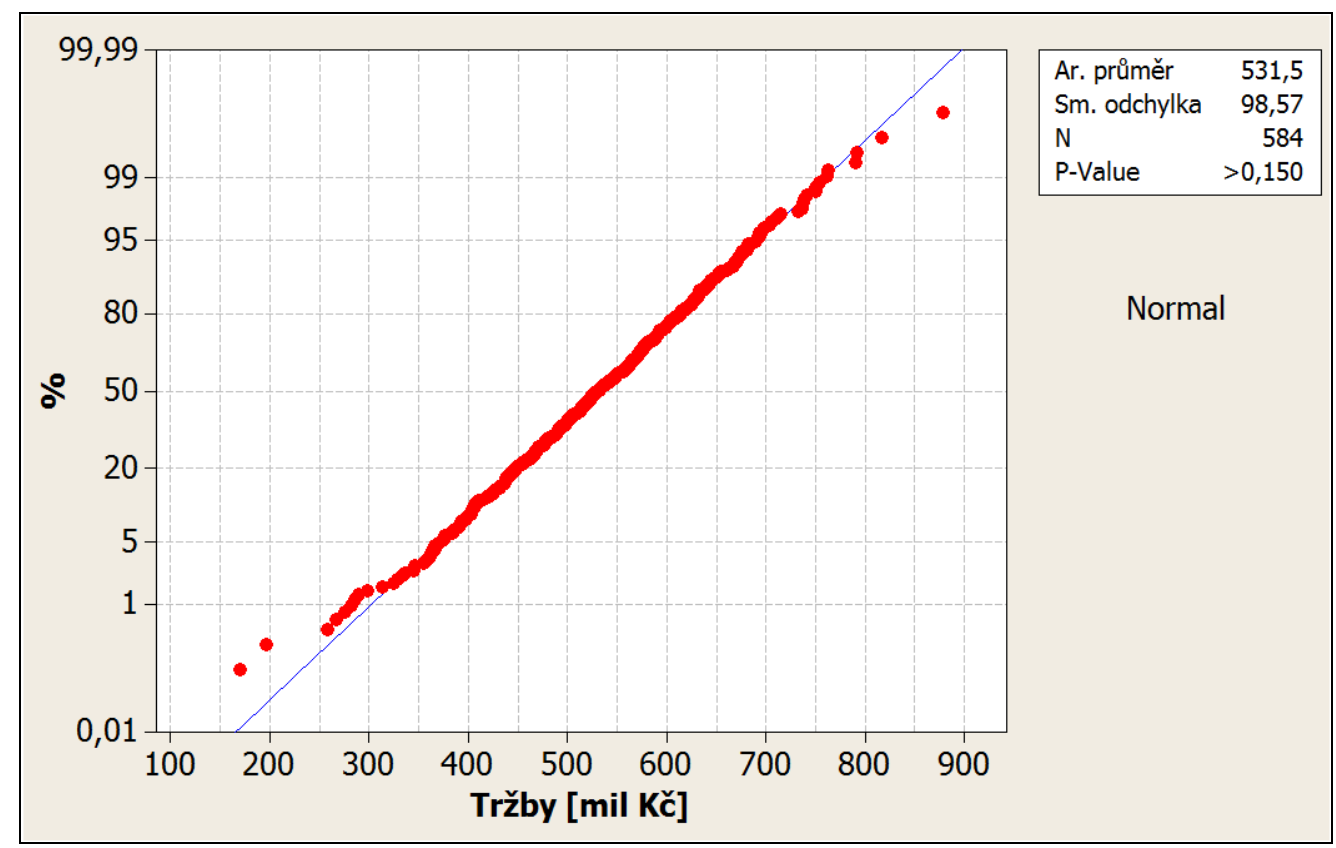

Zdroj: autor - výpočet SW MINITAB 
Obrázek 5: Anderson - Darlingův test normality dle tržeb v mil. Kč

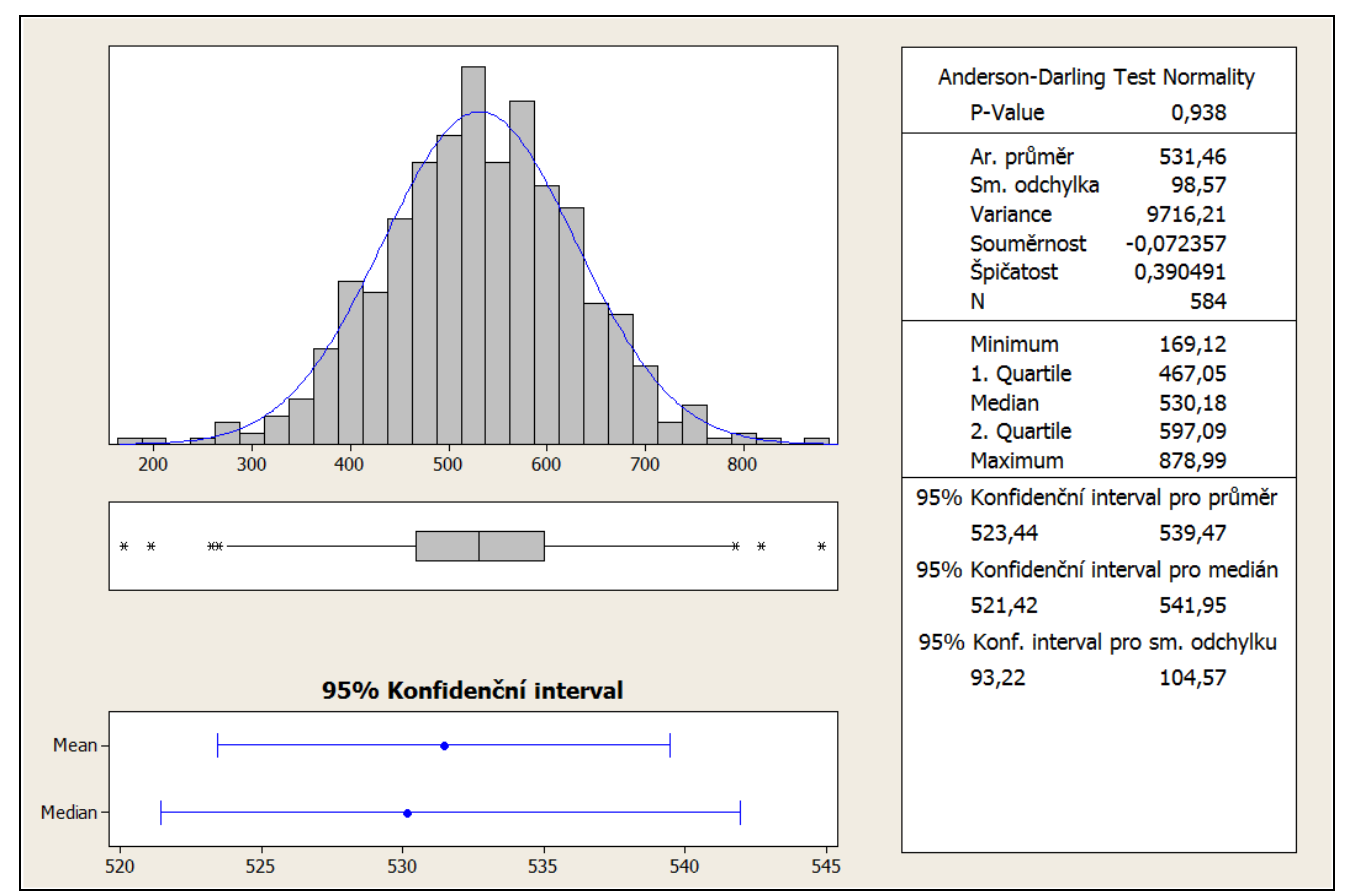

Zdroj: autor - výpočet SW MINITAB

Obrázek 6: Graf - Kolmogorov - Smirnofưv test normality dle počtu zaměstnanců

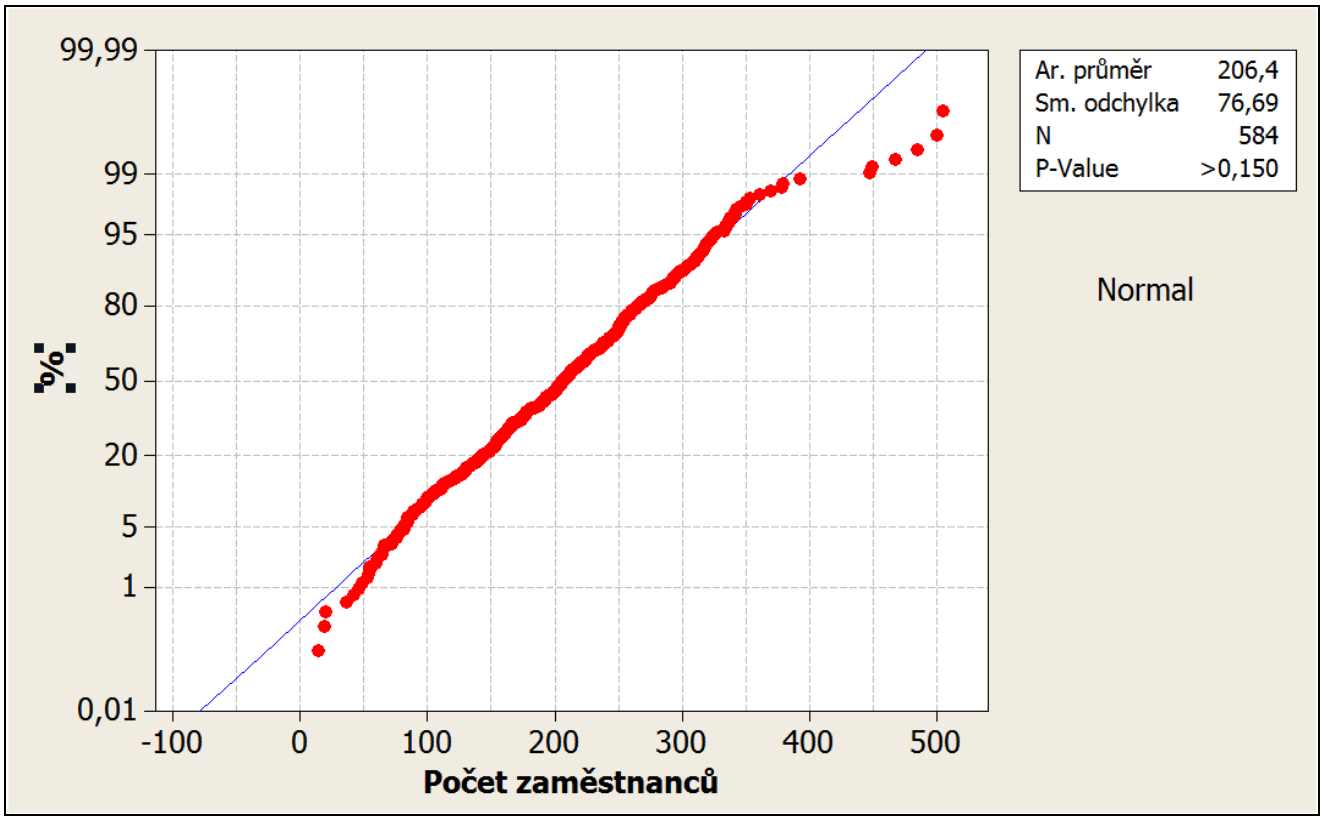

Zdroj: autor - výpočet SW MINITAB 
Obrázek 7: Anderson - Darlingův test normality dle počtu zaměstnanců

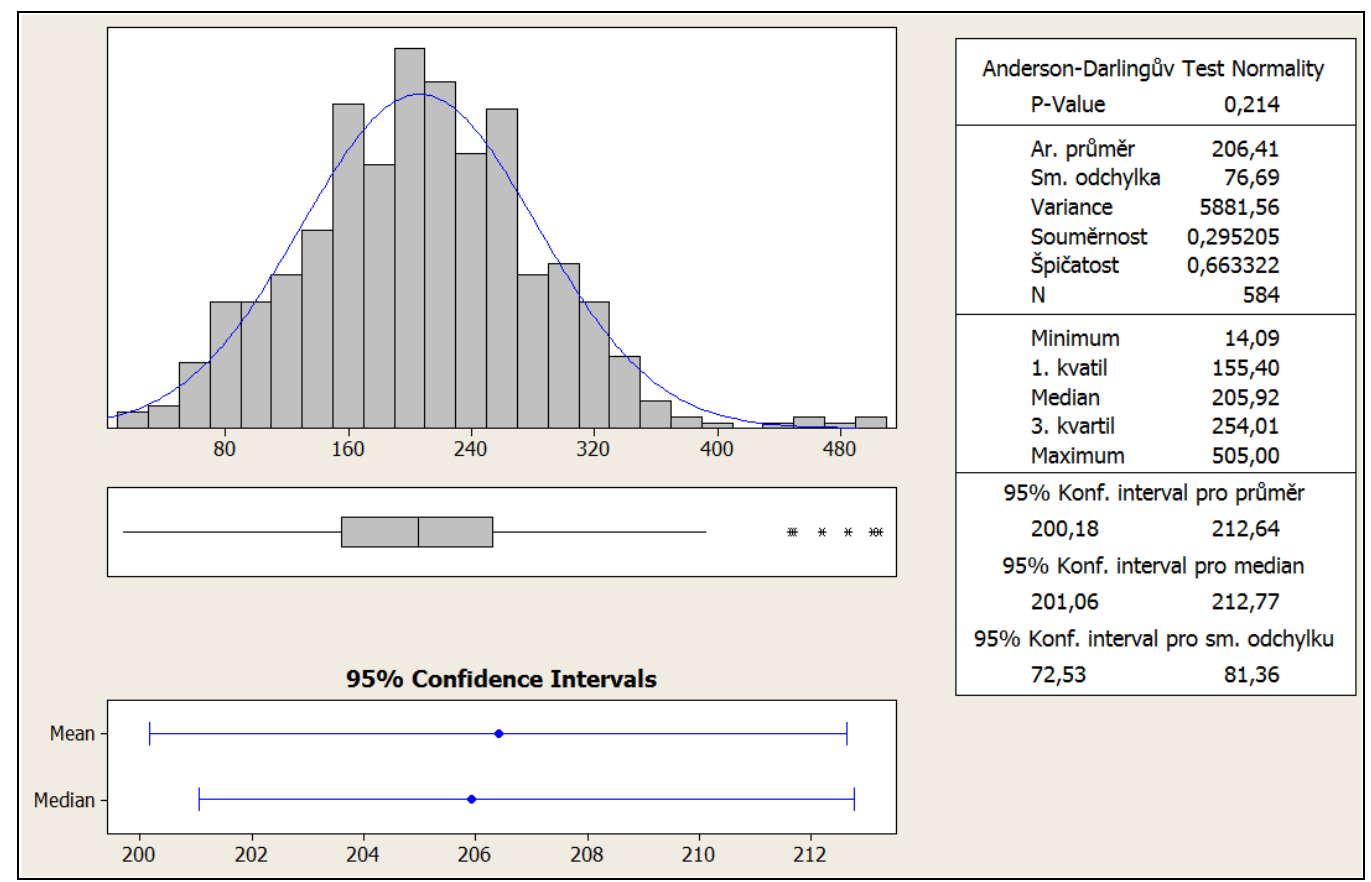

Zdroj: autor - výpočet SW MINITAB

\section{Hypotézy}

Pro obě skupiny respondentů byly definovány následující rozdílné hypotézy. Pro první skupiny jsou to hypotézy $\mathrm{H}_{1}$ až $\mathrm{H}_{3}$, pro druhou skupiny hypotézy $\mathrm{H}_{4}$ až $\mathrm{H}_{8}$ :

První skupina-

$\mathrm{H}_{1}$ : Manažeři neznají problematiku simulace výrobních a logistických systémů.

$\mathrm{H}_{2}$ : Podniky používají spíše jiné nástroje na optimalizaci než je simulace.

$\mathrm{H}_{3}$ : Většina podniků má problémy s plánováním výroby.

Druhá skupina-

$\mathrm{H}_{4}$ : Př́i prezentaci výsledků simulačních projektů se vyskytuje velká nedůvěra manažerů firem.

$\mathrm{H}_{5}$ : Simulace se nepoužívá na plánování a řízení výroby.

$\mathrm{H}_{6}$ : Většina uživatelů simulačních nástrojů rovněž využívá i optimalizační modul.

$\mathrm{H}_{7}$ : Službu modelování, simulace a optimalizace podnikových procesů lze bez problémů outsourcovat - manažeři se nebrání.

$\mathrm{H}_{8}$ : Modelování simulaci a optimalizaci využívá primárně operační (výrobní) management.

\subsection{Výsledky průzkumu - 1. skupina - manažeři (potenciální uživatelé)}

Závěry z odpovědí 1 . skupiny respondentů poukazují na fakt, že $96 \%$ manažerů se setkalo s pojmem simulace výrobních a logistických systémů a pouze $21 \%$ ji prakticky použilo, uživá a nebo to má v plánu do budoucna. Při návrhu výrobního systému dělá podnikům největší potíže plánování výroby $(58 \%)$ a efektivní využívání strojů a stanovení počtu pracovníků (26,5\%). V obou prŕípadech by pravděpodobně užití simulačního softwaru napomohlo. $63 \%$ respondentů odpovědělo kladně na otázku, jestli mají v podniku nástroj, na kterém je možné modelovat výsledek rozhodnutí. Nejvíce z nich (51\%) uvedlo, že takový nástroj je u nich v podniku součástí informačního systému nebo systému na plánování, $8 \%$ využívá samostatný simulační software a $16 \%$ se spoléhá na MS Excel s doplňky. Další otázky směřovaly do oblasti použití nástrojů pro optimalizaci. Simulaci jako samostatný nástroj uvedlo $11 \%$ dotázaných. Stejné oblibě se těší klasické výpočty. Nejvíce respondentů (41\%) nespoléhá 
pouze na jeden z výše uvedených nástrojů optimalizace a různě je kombinuje s tím, že jako nejvyšší úroveň kontroly stále dominuje lidský faktor. Pouze třetina podniků disponuje simulačním softwarem. V této souvislosti je zajímavé, že $84 \%$ dotázaných by neocenilo možnost poslat svoje varianty rozhodnutí externí firmě, která by jim doporučila nejlepší variantu - graf na obr. 8. Příčinu tohoto postoje lze nalézt i v odpovědi na důvěryhodnost simulace, kdy pouze $8,5 \%$ je velmi spokojeno a $26 \%$ spokojeno částečně (prověřují si výsledky simulace výpočtem). Mezi nástroji používanými na řešení problémů v podniku je nejčastěji uváděn klasický tabulkový kalkulátor typu MS Excel.

Obrázek 8: Ochota manažerů - neuživatelů simulační podpory - využít pro podporu svých rozhodnutí analýzu nástrojem simulační podpory provedenou externí firmou.

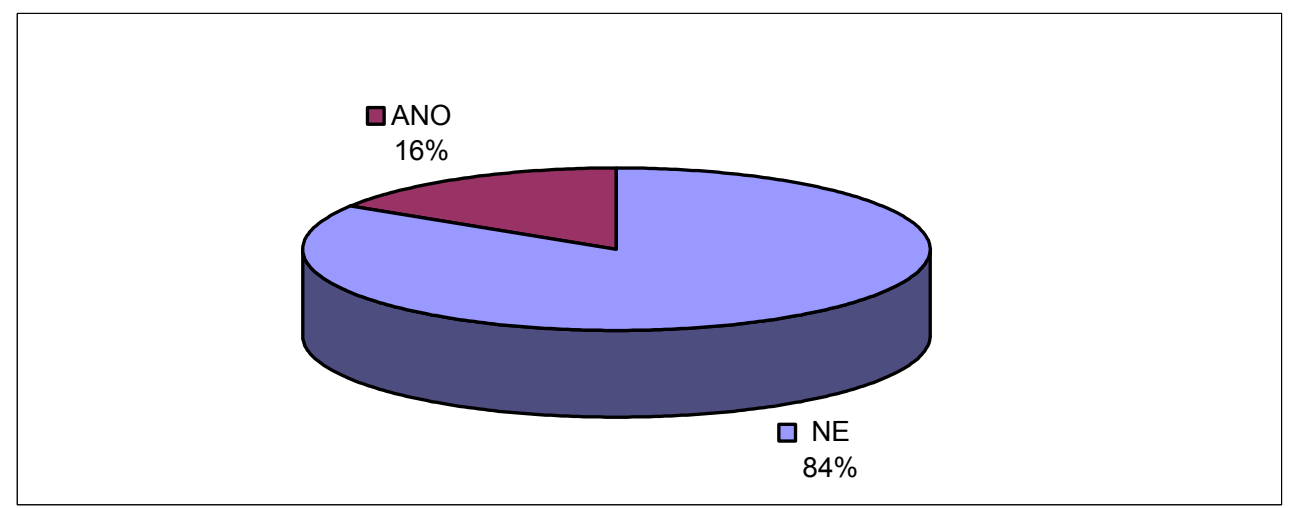

Zdroj: autor

3.2 Výsledky průzkumu - 2. skupina - uživatelé simulační podpory

Z odpovědí 2 . skupiny respondentů na otázku týkající se používání simulace při řízení výroby vyplynulo, že v $11 \%$ př́padů je v podniku on-line propojení výroby se simulačním softwarem (14\% off-line). Respondenti používají simulaci v $11 \%$ př́ípadů jen př́ležitostně. Ve $43 \%$ př́padů je simulace užívána jen pro speciální projekty. Zajímavé je zjištění, že pouze $21 \%$ uživatelů simulační podpory je přesvědčeno o tom, že je výhodnější, když simulaci provádí sami v podniku, než aby ji přenechali externí firmě (outsourcovali). U této části dotazování je pozoruhodný rozdíl názorů na stejnou otázku v porovnání se skupinou dotazovaných, kteří simulační podporu nepoužívají - skupina 1 - graf na obr. 9 a na obr. 10. Tuto druhou variantu by přivítalo $79 \%$ dotázaných uživatelů simulačních nástrojů. Podle jejich názoru v době realizace výzkumu v ČR stále převládala nedůvěra manažerů k výsledkům simulace. $21 \%$ uvádí velmi častou nedůvěru, $14 \%$ je nuceno podpořit výsledky simulace dalšími výpočty, $36 \%$ stále cítí nedůvěru, ale tvrdí, že situace se zlepšuje a konečně pouhých $18 \%$ necítí nedůvěru vůbec. $Z$ odpovědí na využívání optimalizačního modulu plyne, že téměř $79 \%$ respondentů jej používá, dalších $14 \%$ jej hodlá v budoucnu použít. $54 \%$ uživatelů simulačních nástrojů odpovědělo kladně na otázku, zda jsou přínosy použití simulace evidentní, ovšem čtvrtina z nich př́nosy pouze odhaduje. Modelovací a simulační podpora je primárně využívána na úrovni taktického řízení (74 \%) - viz. graf na obr.10. 
Obrázek 9: Ochota manažerů - uživatelů simulační podpory - využít pro podporu svých rozhodnutí analýzu nástrojem simulační podpory provedenou externí firmou.

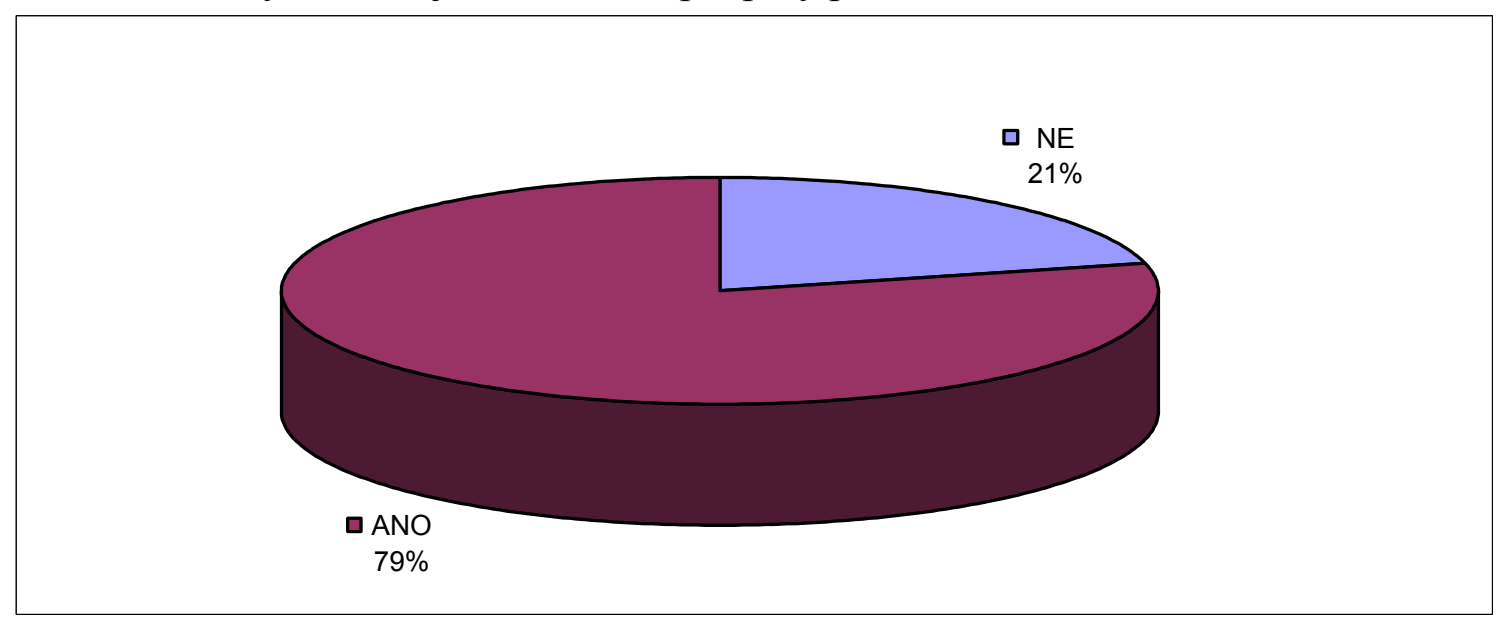

Zdroj: autor

Obrázek 10: Rozdělení manažerů - uživatelů podpory mapování a simulace podnikových procesů dle úrovně ř́zení.

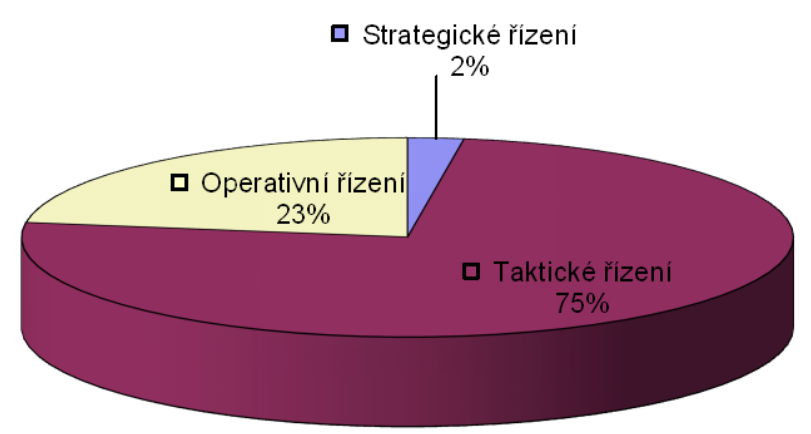

Zdroj: autor

\section{Závěr - výsledky ověřování pracovních hypotéz}

$\mathrm{H}_{1}$ : Hypotéza nepotvrzena. 53\% respondentů má přinejmenším základní teoretické znalosti o simulaci získané na seminářích, školeních nebo konferencích.

$\mathrm{H}_{2}$ : Hypotéza potvrzena. Pro optimalizaci se nejčastěji používají tabulkové kalkulátory a matematické metody.

$\mathrm{H}_{3}$ : Hypotéza potvrzena. Při návrhu výrobního systému dělá manažerům největší potíže plánování výroby.

$\mathrm{H}_{4}$ : Hypotéza potvrzena. Při prezentaci výsledků simulačních experimentů se vyskytuje velká nedůvěra manažerů, která je stále jednou ze zásadních bariér v rozšíření simulace.

$\mathrm{H}_{5}$ : Hypotéza potvrzena. Jen $25 \%$ respondentů uvedlo, že simulaci používá k řízení výroby.

$\mathrm{H}_{6}$ : Hypotéza potvrzena. Simulace se již běžně používá současně s optimalizačním modulem.

$\mathrm{H}_{7}$ : Hypotéza potvrzena. Uživatelé nebo potenciální uživatelé simulační podpory by se nebránili outsourcingu této služby.

$\mathrm{H}_{8}$ : Hypotéza nepotvrzena. Nástroje modelovací a simulační podpory jsou využívány dominantně na úrovni taktického řízení. Nikoliv tedy na úrovni řízení strategické nebo operativní. 


\section{Literatura}

[1] ACKHOFF, R. L. and M. W. SASIENI, 1968. Fundamentals of Operations Research. USA: Wiley \& Sons, Inc. ISBN 0-047-10333-6.

[2] BURIETA, J., 2005. Prieskum v oblasti simulácie výrobných a logistických systémov [online]. [cit.2008-03-10]. Dostupné z: http://www2.humusoft.cz/ www/akce/witkonf06/prispevky/pdf/burieta.pdf

[3] DANĚK, J., 2002. Využití simulace jako inženýrského nástroje během životního cyklu výrobki̊ a procesů [online]. [cit. 2008-03-04]. Dostupné z: http://www2.humusoft.cz/www/pub/witness/ppt/inovacia2002/sld001.htm

[4] DLOUHÝ, M., J. FÁBORY, M. KUNCOVÁ a T. HLADÍK, 2007. Simulace podnikových procesů. 1. vydání Brno: Computer Press. ISBN 978-80-251-1649-4.

[5] KOZEL, R. a kol., 2006. Moderní marketingový výzkum. Praha: Grada Publishing. ISBN 80-247-0966-X.

[6] LAGUNA, M. and R. MARTÍ, 2008. Neural Network Prediction in System for Optimizing Simulations [online]. Dostupné z: http://academic.research. microsoft.com/Paper/3444246

[7] LÖFFELMANN, J., 2004. Trendy v plánování a řízení výroby. IT Systems [online]. 5(7-8) [cit. 2008-03-03]. Dostupné z: http://www.systemonline.cz/clanky/trendy-vplanovani-a-rizeni-vyroby-i-dil.htm

[8] MANLIG, F., 2000. Počítačová simulace výrobních procesů [on line]. [cit. 2008-03-04]. Dostupnéz: http://www.humusoft.cz/pub/witness/manlig/manlig2.htm

[9] PUNCH, K. F., 2008. Úspěšný návrh výzkumu. 1. vydání. Praha: Portál. ISBN 978-807367-468-7. 